\title{
The Financial Setting for FDI Inflows into The Czech Republic and Slovakia
}

\author{
Edward M. Jankovic, D.I.B.A. \\ Fairfield University, 1073 N Benson Rd., Fairfield, CT 06824, USA \\ and \\ Lubin School of Business, Pace University, 1 Pace Plaza, New York, NY 10038, USA \\ Tel: 1-(203)-445-9303 E-mail: intlbusiprof@optonline.net \\ Pan G. Yatrakis, Ph.D. (Corresponding Author) \\ Huizenga School of Business, Nova Southeastern University \\ 3301 College Ave., Ft. Lauderdale, FL 33314-7796, USA \\ Tel: 1-(954)-262-5098Ｅ-mail: yatrakis@huizenga.nova.edu
}

Received: July 28, 2010 Accepted: August 18, 2010 doi:10.5539/ibr.v4n3p45

\begin{abstract}
This study examines the relationship between foreign direct investment in the Czech Republic and Slovakia and such potentially explanatory factors as trade flows, measures of economic and financial stability, and country risk. The authors find that as the Czech and Slovak Republics progress toward market economies, some policy points to consider include: transparency of markets, economic systems, social and political organizations; an increase in commerce and investment, which makes reversals of reforms less likely and the condition of financial factors that contribute to increased investment.

At this time, these transition economies possess many of the resources needed for development, such as educated labor forces, an entrepreneurial orientation among the citizens, and available land. Yet, another key resource, capital, is in short supply in the region. An important precondition to obtaining capital is the demonstration of economic and political stability (see Kyrkilis and Pantelidi 2006). By improving the transparency of their legal, banking, and capital markets sectors, the Czech and Slovak Republics can accelerate their progress toward free markets and democratic societies.

Our research finds that relationships exist among country risk ratings, financial market variables, and expected returns in this region; such relationships can be useful in developing policies to improve capital markets and attract external capital. The importance of building upon other researchers in this field updates that research plus incorporates new aspects of issues now developing. This research topic is fluid and demands continuous review and testing.
\end{abstract}

Keywords: FDI, Foreign direct investment, Country risk, Transition economies, Czech Republic, Slovakia

JEL classification: F15, F30, G15, O57

\section{Introduction}

As the Czech and Slovak Republics continue their transition toward market economies, the transparency of their financial, social and political systems assumes increasing importance as a determinant of international commerce and foreign investment in their economies. Increased commerce and investment, in turn, make reversals of economic reforms less likely and contribute to a virtuous cycle of economic development. The relationship between transparency and investment is recognized by Roland (2002), Wade (2005), and Kyrkilis and Pantelidi (2006), all of whom discuss foreign direct investment (FDI) and its effect on political risk issues of social and legal transparency.

Like other economies in transition, those of the Czech Republic and Slovakia possess many of the critical resources needed for development, such as educated labor forces, an entrepreneurial spirit, and available land. Yet capital, the final key factor of production and economic development, remains in short supply throughout the region. An important precondition in obtaining capital is economic and political stability (see Wade 2005; Roland 2002). By 
continuing to improve the transparency of their legal, banking, and capital markets sectors, the Czech and Slovak Republics may be able to accelerate their progress toward market-based economic development.

The purpose of the present research is to test for the existence of relationships among country risk ratings, financial market variables, and expected returns in this region, and to determine whether any such relationships can be useful in developing policy initiatives to attract more capital. This area of research has been the focus of several recent studies (Bekaert, Harvey and Lundblad 2009), and policies based on the results are still being tested.

The transitional economies of Europe face not only internal issues concerning their own economies and political systems, but also the consequences of participating in the larger economic and political organization of the European Union (EU). One such consequence, the sovereign credit ratings after accession, has been investigated by Hauner, Jonas and Kumar (2007) and carries the potential of abuse through excessive borrowing, as illustrated by Greece and other countries on the Eurozone's fringe. The findings of the present research should therefore also be of interest to policymakers responsible for overseeing these countries' legal, banking, and capital markets mechanisms and their harmonization with those of the larger economic and political groupings to which the Czech and Slovak Republics belong. Our study extends the work of previous researchers Baekert and Harvey (2002), Hauner, Jonas, and Kumar (2007), and Kyrkilis and Pantelidis (2006) by examining the applicability of their findings to current conditions and newly emerging capital markets.

\section{Methodology}

The dependent variable in this study is FDI. Explanatory variables examined include the focus country's current account (CA), consumer prices (CPI), exchange rate (XR), long-term lending rate (LR), stock market index (SM), and the Fitch index of country risk (CR).

The equation for the assessment of factors affecting FDI is as follows:

$\operatorname{FDI}(t, j)=f(C A(t, j), C P I(t, j), \operatorname{SM}(t, j), X R(t, j), L R(t, j))$

with $\mathrm{j}$ signifying the focus country and $\mathrm{t}$ representing each time period of quarterly data from 1995 through 2006. The relationship between country risk, FDI, and each other variable is shown by:

$$
\operatorname{FDI}(t, j)=f(C R(t, j))
$$

where CR represents country risk as rated by Fitch.

Both Vector Autoregression (VAR) and Cointegration analysis are used. VAR determines the optimal lag in the relationship, indicating how long after an event its effect is felt. Johansen Cointengration (Johansen 1988) identifies long-term relationships among variables that may be obscured by short-term movements, as in the communication problem of separating the message from the medium of transmission, or the economic problem of differentiating between a random movement and a correction back to equilibrium.

\section{Results}

The results of the VAR analysis for the Czech Republic are presented in Table 1. FDI is found to be very robust, having a strong autoregressive effect with a one period lag. It is rather stable, with a rise in one quarter correcting by a smaller amount in the next. When CA improves, there is a pronounced positive effect on FDI three periods thereafter, and a less significant but also strong effect in the fourth period following CA improvement. Krkoska (2001) discusses the relationship of CA deficits and the need to cover them with FDI inflows.

There is also a mild positive effect on FDI resulting from a strengthening of the XR in each of the previous periods but without any clear conclusions. The LR has a strong effect on FDI with a three period lag. Depending on how long money takes to move through the pipeline to project initiation, and on the capital intensity of the project, this may also relate to some of the XR and CA effects.

The SM variable has a noticeable effect on FDI with one lag, possibly indicating substantial co-financing from this source. Krkoska (2001) also discusses links between FDI and other sources of financing. The hypotheses for CA, $\mathrm{SM}$, and LR are supported with this analysis, and there is some support for the hypothesis with variable XR.

Risk rating changes, both negative and positive, manifest immediate and direct effects on SM movements. Positive risk rating changes seem to affect FDI flows relatively quickly, while the one negative change in 2001Q1 only seemed to dampen or delay an upward move, which occurred four periods later. FDI is much more volatile than SM, but with two exceptions, 2003Q4 and 2005Q3, these two variables are positively correlated. This observation supports the results of the VAR analysis.

For Slovakia, the overall robustness observed in the VAR analysis is low. The low adjusted R2 indicates diffusion in the ability of the independent variables to explain FDI. A strong corrective effect of a two-period lag on FDI is clear, 
and there is a mild corrective effect from the one period lag. There is also a mild effect of XR with a three period lag. Therefore, FDI is observed to display a stable accumulation trend, while an appreciation of the dollar decreases FDI three periods following the event. The hypothesis for XR has some support for Slovakia (see Table 2). Changes in Slovakia's country risk rating have direct effects on SM and FDI, with only a short, one-period lag.

The FDI/SM relationship can be broken into short-term and long-term effects. Movements in short-term SM track FDI movements very closely, although they are not as volatile. Long-term movements were inverse to those in FDI during the first six years of the time period analyzed, but began moving in the same general direction in 2001. Again, FDI flows are much more volatile than SM movements.

Results obtained using Johansen Cointegration indicating that FDI is cointegrated with CA, XR, SM, CPI, and LR (see Table 3).

All variables were tested for stationarity using the ADF (Augmented Dickey-Fuller) Test and the majority are non-stationary at their levels and thus suitable for cointegration testing but not for least squares time series regression analysis (see Tables 4 and 5).

The cointegration equation for each country is described with the standard error in parentheses below the coefficient. Results are discussed for each country.

\subsection{Czech Republic}

FDI $=+3.44 \mathrm{CA}-516.84 \mathrm{XR}-.153863 \mathrm{SM}+7411.640 \log \mathrm{CPI}-586.712 \mathrm{LR}$

(0.76339) (97.201) (2.043)

For the Czech Republic, FDI cointegration with CA is strongest; cointegration with the exchange rate, logCPI, and the lending rate are fairly significant; while cointegration with the stock market is insignificant. Four of our five hypotheses are therefore supported by cointegration analysis. FDI flows into the Czech economy have been affected by merger and acquisition activity on an international level which, according to Brada, Kutan and Yigit (2004) influenced the Czech Republic's SM. In the Brada, Kutan and Yigit (2004) study, this relationship did not materialize, possibly because they did not use cointegration as an adjustment for the short-term effects of merger and acquisition activity on the overall stock market. Changes in country risk ratings have had an effect on CA in only two out of three occurrences, not useful or reliable information. However, CA does track closely the moves in FDI, with only two or three exceptions over the eleven-year period of the study. This observation is in line with the results of both the VAR and the cointegration analyses. LR is also affected by the all three credit risk rating changes, and its inverse movement relative to CR is likewise evident from the results of the cointegration analysis.

\subsection{Slovakia}

$\mathrm{FDI}=+0.3778 \mathrm{CA}+122.48 \mathrm{XR}+2.5866 \mathrm{SM}-28808.98 \log \mathrm{CPI}-99.643 \mathrm{LR}+504.92 \mathrm{ttrend}$

$$
\text { (0.2018) (27.403) (1.8386) (6246.41) (32.851) (110.045) }
$$

A time trend variable was inserted into this equation because no cointegration results could be obtained without its inclusion. Thus, this is a deterministic vector, as compared to all our other equations, which are stochastic.

FDI was found to be very significantly cointegrated with all variables except $\log$ CPI, where cointegration was found to be insignificant. Therefore, all hypotheses except that regarding inflation are supported, and this medium-sized transition economy's sources of FDI are found to respond to changes in the variables described in previous research (see Jankovic 2008).

One common determinant of FDI identified in both countries by cointegration analysis is the exchange rate (XR) which has a strong effect. This result implies that policy actions which strengthen a currency tend to increase FDI, while currency weakness tends to discourage FDI inflows. FDI and other financial flows in turn contribute to higher growth (Schadler et al 2006), the key policy objective in attracting FDI. The current account (CA) is another common driver of FDI, with a strong effect in both countries. This finding supports the research of Schadler et al (2006), which shows that CA improvements affect FDI and other financial flows, with a direct impact on economic growth. SM showed a strong effect as a determinant on Slovakia but not in the Czech Republic. Finally, LR also displayed a strong effect on FDI in both countries.

It should be noted that these outcomes are somewhat more definitive than those obtained with VAR analysis, which does not produce such clusters of results. Of the variables tested with VAR, SM and CA effects are evident in the Czech Republic but not in Slovakia; XR effects are mildly evident in both the Czech Republic and Slovakia.

Risk rating changes affected Slovakia's CA in four of the five times that such events took place, as evidenced in Figure 1. A negative change or outlook narrows the CA deficit, while a positive change widens it, albeit by a small 
amount for the 2003Q2 event. The effect of risk rating changes effect on FDI is direct and immediate in the period following, while the FDI/CA relationship is almost exactly inverse in the short-term, implying that foreigners are financing trade-related investment.

A negative rating or outlook here has a very short-term inverse effect on LR (see Figure 2). Conversely, a positive rating or outlook change seems to continue the downtrend in LR. In light of the clear, overall seven-year downtrend, it is inconclusive that positive risk rating changes are solely responsible for the continuing decline in LR. Risk rating changes have immediate direct effects on FDI, some only short-term and some more sustained. No conclusive pattern is discerned between FDI and LR, although the variables seem to converge in recent years, indicating increased stability of the relationship compared to the early years of the analysis.

Country risk rating changes have an inverse effect on XR in Slovakia and a very short-term direct effect on FDI, as illustrated in Figure 3. The relationship between FDI and XR is similar to patterns in other transforming economies (Jankovic 2008): in the early years of the time period examined, the trends move together. However, in recent years, those trends themselves converge. This indicates a more stable relationship between the variables, and is supported by the results of both the VAR and cointegration analyses.

\section{Conclusion}

At the present time, the focus of Europe's political and economic revolution is the expansion of the European Union and the advantages and problems inherent in that expansion. The recent sovereign debt crisis underscores the fact that one size does not always fit all, even among developed economies like France and The Netherlands, both of which at one time rejected in referenda earlier versions of the Lisbon Treaty (Vasallo 2009). It is hoped that this paper's research may be of help to accession countries in elaborating policies and strategies to further the development of their economies.

One limitation of this research is the short, ten-year time span examined. Updating this study in four to six years when additional data becomes available to reflect the repercussions of the sovereign credit crisis of 2010 would be a worthwhile endeavor. Further research might also include the use of spreads, or differentials, of the interest rate components for cross-country comparisons. Also useful might be the application of the current analytical methodology to the next potential wave of accession countries.

FDI is necessary for many countries' continued economic growth. Ben Bernanke discusses how capital flows to developing economies afford those countries ways to take advantage of investment opportunities while providing savers with mechanisms to earn better returns and reduce risk. Access to the international capital markets also allows countries to acquire foreign assets in boom times and use those assets in lean times, thereby creating a buffer to adverse changes in domestic income and production (Bernanke 2005). Even the USA is tremendously dependent on foreign capital to finance its domestic and international growth. No matter how advanced an economy, or perhaps the more advanced an economy, the more important foreign trade and investment are in bringing it to the next level of advancement. Recalling the thought of Hugh of Saint Victor (Acton Institute 2007), trade and commerce are the best proven prescriptions for peaceful economic growth and advancement.

A practical reason to promote a more stable financial environment in the Czech and Slovak economies is to attract the financial flows necessary to help fund the many required activities and programs of accession to EU membership. A further reason to promote a more stable financial environment in these countries is to improve standards of living and quality of life. Therefore, the study of relationships among country risk, investor expectations, and financial variables provides valuable information to countries striving to improve the liquidity and transparency of their markets and progress toward freer, more independent, and more democratic societies. With more transparency come less corruption, improved laws, and a clearer perspective in determining policy.

The increased need for capital in the transforming economies covered in this study can only be satisfied at this time from investors outside the region (Slovak Economics Ministry 2009). Using and improving domestic markets is important for long term benefits, yet current needs must come from FDI, other financial inflows, syndicated loans, and flexible financing mechanisms (Goldberg 2007) It is therefore all the more important that foreign investors view these accession countries as secure destinations for investments. And with the robust growth of local and regional markets, the participants in those markets, as well as fiscal and monetary authorities and foreign policymakers will all benefit from the increased information provided by the marketplace.

\section{References}

Acton Institute. (2007). Academic Research Center, Studies in Ethics and Economics, In The Liberal Tradition. A History of Liberty - Collection of Biographies. Retrieved April 12, 2007 from http://www.acton.org/publicat/randl/liberal.php?id=33. 
Appel, Gerald. (2005). Technical Analysis: Power Tools for Active Investors. Upper Saddle River, New Jersey. Pearson Education, Inc., Financial Times/Prentice Hall.

Baekert, Geert, and Campbell R. Harvey. (2002). Research in Emerging Markets Finance: Looking to the Future, Emerging Markets Review, 429-448.

Baekert, Geert, Campbell R. Harvey, and Christian Lundblad. (2009). Financial Openness and Productivity,"Emerging Markets Finance Conference at City University, London.

Bernanke, Ben, S. (2005). Monetary Policy in a World of Mobile Capital, Cato Journal, 25 (1).

Brada, Josef C., Ali M. Kutan, and Taner M. Yigit, (2004). The Effects of Transition and Political Instability on Foreign Direct Investment Inflows: Central Europe and the Balkans, ZEI Working Paper No. B33. Center for European Integration Studies. Bonn.

The Economist. (2009). Issues Oct. 12 and April 10, 2009.

Edwards, R.D. and Magee, J. (1966). Technical Analysis of Stock Trends. (5 ${ }^{\text {th }}$ ed.). Boston: John Magee Publishers, Inc.

Fitch Ratings. (2006). Emerging Europe Sovereign Review - 2006. May 2006.

Goldberg, Linda S. (2007). Federal Reserve Bank of New York Economic Policy Review, March 2007.

Harvey, Campbell R. (2004). Country Risk Components, the Cost of Capital, and Returns in Emerging Markets, NBER abstract 620710. Cambridge, Mass.

Hauner, David, Jonas, Jiri and Kumar, Manmohan. (2007). Policy Credibility and Sovereign Credit - The Case of New EU Member States (January 2007). IMF Working Paper No. 07/01 Available at SSRN: http://ssrn.com/abstract $=956766$

Jankovic, Edward M. (2008). Country Risk and Common Drivers of FDI in Central Europe - Innovative Methodology Employed, Paper presented at the $65^{\text {th }}$ International Atlantic Economic Conference, Warsaw, April 2008.

Johansen, S. (1988). Statistical Analysis of Cointegration Vectors, Journal of Economic Dynamics and Control, 12: 231-254.

Krkoska, L. (2001). Foreign Direct Investment Financing of Capital Formation in Central and Eastern Europe, EBRD Working Paper No. 67 December 2001.

Kyrkilis, D. and Pantelidis, P. (2006). European Union Entry and Foreign Direct Investment Flows into Central and Eastern Europe, Paper presented at the European Association for Comparative Economics Studies (EACES) $9^{\text {th }}$ Annual Conference: Development Strategies - A Comparative View. September 2006.

Lloyd,J. (2006, June 3). Let's just stick to the issues. The Financial Times, p. W3.

Roland, Gerard. (2002). The Political Economy of Transition, Journal of economic Perspectives, 16 (1): 29-50.

Schadler, S., Mody, A., Abiad, A., and Leigh, D. (2006). Growth in the Central and Eastern European Countries of the European Union. International Monetary Fund Occasional Paper No. 252. Washington, D.C.

Slovak Economics Ministry. (2009). Slovak Government Sees Revival in FDI Inflows, at Reuters: http://www.reuters.com/article/idUSLM64277020091022 on April15, 2010.

Vassallo, Francesca. (2009). The Failed EU Constitution Referendum: The French Case in Perspective, Paper presented at the annual meeting of the The Midwest Political Science Association, Palmer House Hilton, Chicago, Illinois, May 2009.

Wade, Jared. (2005). Political Risk in Eastern Europe, Risk Management, 52 (3): 24-30. 
Table 1. Vector Autoregression (VAR) Results - CZECH REPUBLIC

\begin{tabular}{|c|c|c|c|c|}
\hline Change in FDI affected by: & Lag & Coefficient & T Statistic & Diagnostic Tests \\
\hline Change in prev periods FDI & 1 & -0.521 & -2.07 & \\
\hline Change in CA & $\begin{array}{l}3 \\
4 \\
\end{array}$ & $\begin{array}{l}-1.18 \\
-1.2721 \\
\end{array}$ & $\begin{array}{r}-2.03 \\
-1.81 \\
\end{array}$ & $\begin{array}{l}- \\
\mathrm{R} 2=.399\end{array}$ \\
\hline Change in XR & $\begin{array}{l}1 \\
2 \\
3 \\
4\end{array}$ & $\begin{array}{l}-176.000 \\
154.735 \\
215.191 \\
222.285 \\
\end{array}$ & $\begin{array}{r}-1.42 \\
1.11 \\
1.45 \\
1.49 \\
\end{array}$ & $\begin{array}{l}\mathrm{AIC}=16.68 \\
\mathrm{SC}=17.74 \\
\text { Log likelihood }=-308.60\end{array}$ \\
\hline Change in SM & 1 & 6.936 & 1.77 & \\
\hline Change in $\log \mathrm{CPI}$ & inc & inc & inc & \\
\hline Change in LR & 3 & 1050.456 & 2.11 & \\
\hline
\end{tabular}

Table 2. Vector Autoregression (VAR) Results - SLOVAKIA

\begin{tabular}{|l|c|l|l|l|}
\hline Change in FDI affected by: & Lag & Coefficient & T Statistic & Diagnostic Tests \\
\hline Change in prev periods FDI & 1 & 0.479 & 1.53 & \\
& 2 & -0.642 & -2.135 & - \\
\cline { 1 - 4 } Change in CA & inc & inc & inc & R2 $=0.105$ \\
\cline { 1 - 4 } Change in XR & 3 & 216.621 & 1.433 & AIC $=16.58$ \\
\cline { 1 - 3 } Change in SM & inc & inc & inc & SC $=17.63$ \\
\cline { 1 - 3 } Change in log CPI & inc & inc & inc & Log likelihood $=-306.57$ \\
\cline { 1 - 3 } Change in LR & inc & inc & inc & \\
\hline
\end{tabular}

Table 3. Cointegration Results

\begin{tabular}{|l|l|l|l|l|}
\hline Country & No. of Cointegration Equations & Trace Statistic & McKinnon .05 Critical Value & Prob. \\
\hline Czech Rep & 1 & 118.27 & 95.75 & .0006 \\
& 2 & 77.01 & 69.82 & .0119 \\
& 3 & 48.00 & 47.86 & .0484 \\
\hline Slovakia & 1 & 122.64 & 117.71 & .0234 \\
\hline
\end{tabular}

Table 4. Augmented Dickey-Fuller test of stationarity - CZECH REPUBLIC

\begin{tabular}{|c|c|c|c|c|}
\hline \multicolumn{5}{|c|}{ Sample Regression t Satistic } \\
\hline Stock Market & 43 & 0.1285 & $3.9802>99 \%$ & Unit root NOT rejected \\
\hline Current Account & 45 & -0.6045 & $-4.10451 \%-3 \%$ & \\
\hline Exchange rate LCU:US\$ (end-period) & 44 & -0.0597 & $-1.037290 \%-95 \%$ & Unit root NOT rejected \\
\hline Lending interest rate (\%) & 45 & -0.0209 & $-0.785695 \%-98 \%$ & Unit root NOT rejected \\
\hline Deposit interest rate $(\%)$ & 44 & -0.0136 & $-0.511198 \%-99 \%$ & Unit root NOT rejected \\
\hline CPI & 45 & -0.0361 & $-3.23515 \%-10 \%$ & \\
\hline FDI & 45 & -0.7519 & $-5.0679<1 \%$ & \\
\hline
\end{tabular}

Table 5. Augmented Dickey-Fuller test of stationarity - SLOVAKIA

\begin{tabular}{|c|c|c|c|c|}
\hline \multicolumn{5}{|c|}{ Sample Regression t Satistic } \\
\hline Stock Market & 43 & 0.0234 & $0.5034>99 \%$ & Unit root NOT rejected \\
\hline Current Account & 44 & -0.5556 & $-4.09621 \%-3 \%$ & \\
\hline Exchange rate LCU:US\$ (end-period) & 44 & -0.0437 & $-1.072790 \%-95 \%$ & Unit root NOT rejected \\
\hline Lending interest rate (\%) & 44 & -0.0242 & $-0.617295 \%-98 \%$ & Unit root NOT rejected \\
\hline Deposit interest rate (\%) & 44 & -0.0010 & $-0.0296>99 \%$ & Unit root NOT rejected \\
\hline CPI & 45 & 0.0028 & $0.2329>99 \%$ & Unit root NOT rejected \\
\hline FDI & 44 & -0.5888 & $-4.2125<1 \%$ & \\
\hline
\end{tabular}




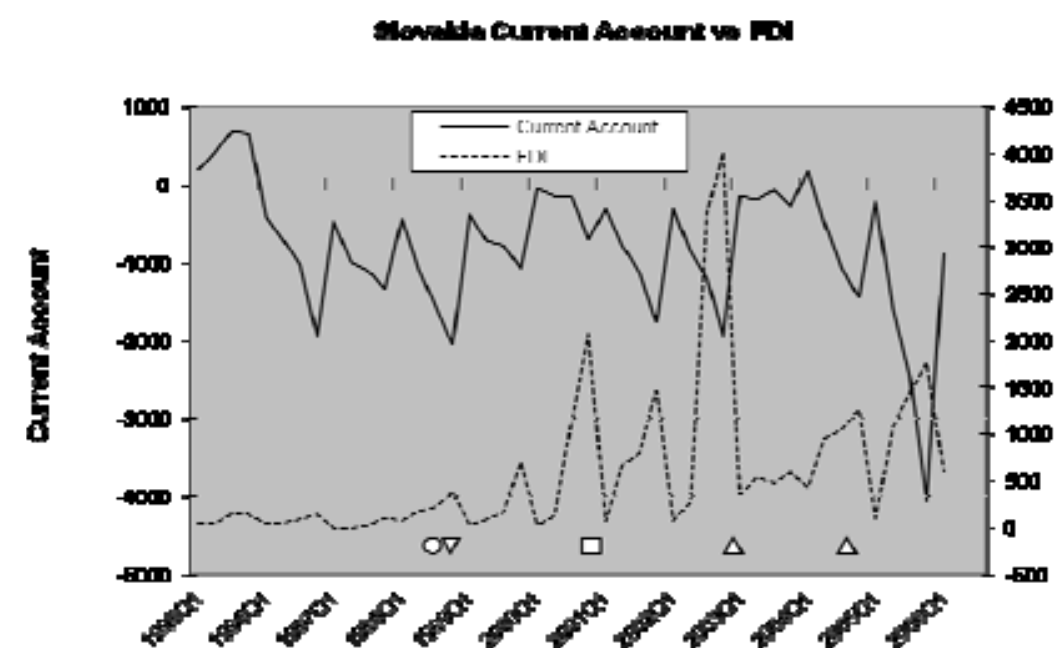

Figure 1.

Indicates a positive risk rating change

. Indicates a negative risk rating change . Indicates outlook changed to positive . Indicates outlook changed to negative

\section{Sqovakia Lending Rate ws FDI}

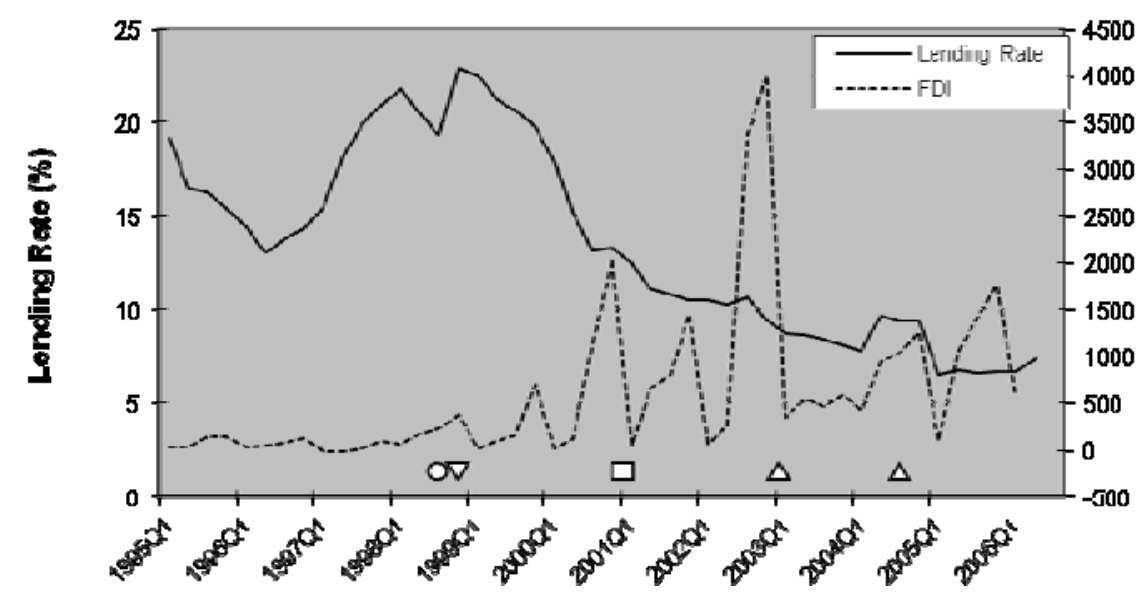

Figure 2

. Indicates a positive risk rating change

. Indicates a negative risk rating change

. Indicates outlook changed to positive

. Indicates outlook changed to negative 
Slovalis Exchangekatev" FUL

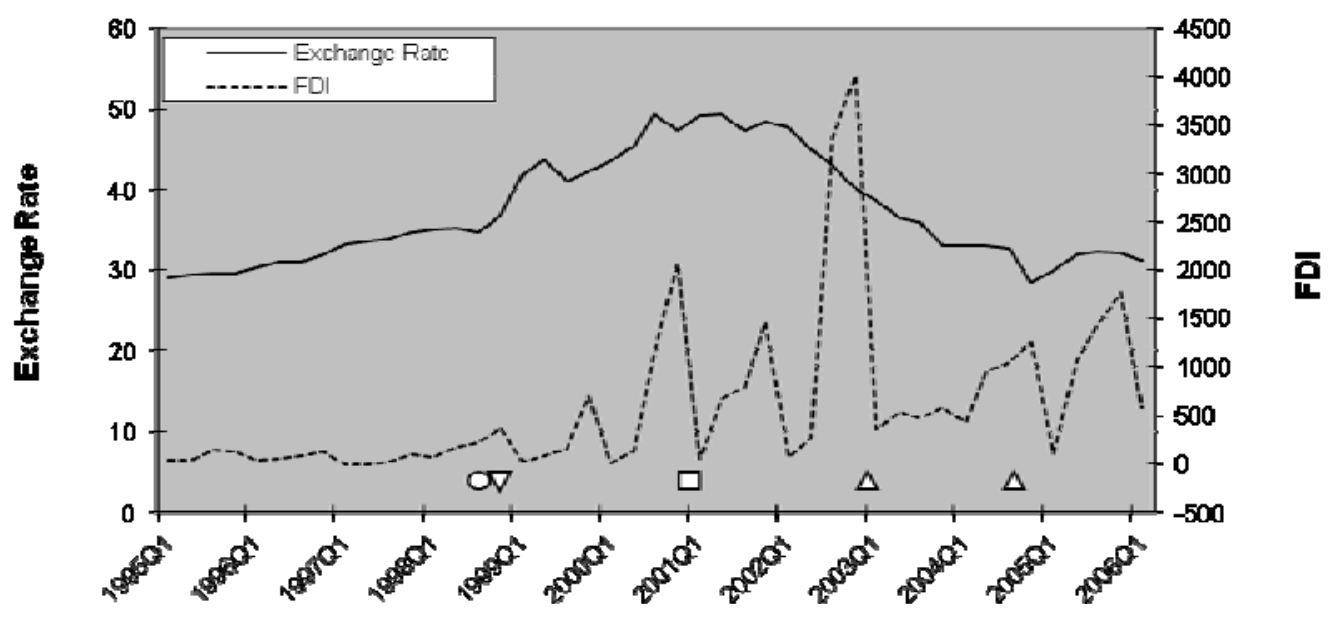

Figure 3.

. Indicates a positive risk rating change

. Indicates a negative risk rating change

. Indicates outlook changed to positive

. Indicates outlook changed to negative 